\title{
Working
}

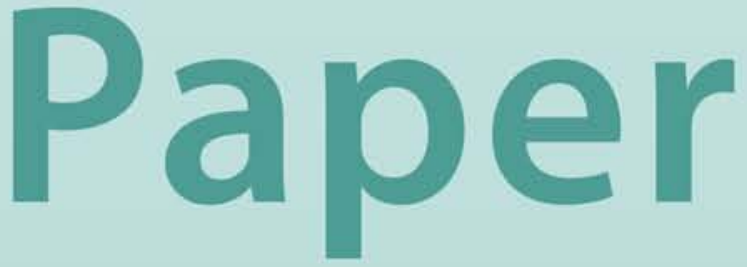


The Impact of U.S. Economic Growth on the Rest of the World: How Much Does It Matter?

Vivek Arora and Athanasios Vamvakidis 


\title{
IMF Working Paper
}

Western Hemisphere Department and European I Department

\section{The Impact of U.S. Economic Growth on the Rest of the World: How Much Does It Matter?}

\author{
Prepared by Vivek Arora and Athanasios Vamvakidis ${ }^{1}$
}

Authorized for distribution by Steven Dunaway and Thomas Krueger

August 2001

\begin{abstract}
The views expressed in this Working Paper are those of the author(s) and do not necessarily represent those of the IMF or IMF policy. Working Papers describe research in progress by the author(s) and are published to elicit comments and to further debate.
\end{abstract}

This paper provides a quantitative assessment of the impact of economic growth in the United States on growth in other countries. Using panel data estimation, the paper finds a significant positive impact of U.S. growth on growth in the rest of the world, especially developing countries, during the past few decades. The evidence suggests that the impact of U.S. growth on other countries can be explained by the significance of the United States as a global trading partner. The paper provides estimates of the direct impact of trade with the United States on growth in several individual countries.

JEL Classification Numbers: F4, O4

Keywords: Economic growth, international trade

Authors' E-mail Address: varora@imf.org, avamvakidis@imf.org

\footnotetext{
${ }^{1}$ The authors are grateful to Steven Dunaway, Thomas Krueger, Olivier Jeanne, Prakash Loungani, and participants in a European I Department seminar for helpful comments and suggestions.
} 


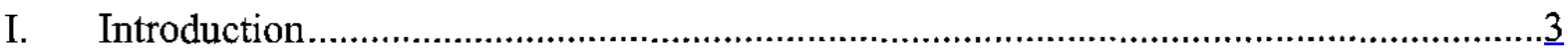

II. How Much Does U.S. Economic Growth Matter for Growth in the

Rest of the World?

A. The Role of the United States as a Trading Partner ...............................................

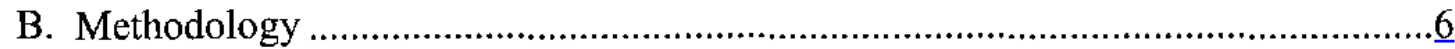

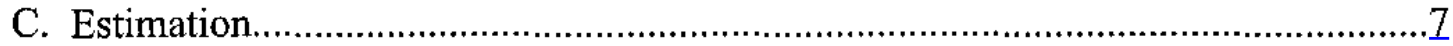

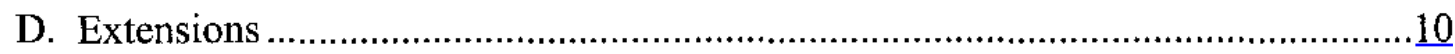

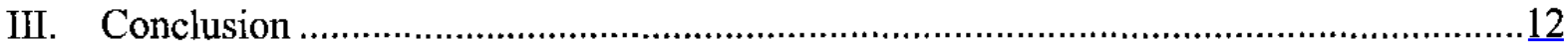

Tables

1. Selected Countries: Role as Trading Partners for Other Countries ...............................13

2. Selected Countries: Merchandise Trade With the United States as a

Percent of Total Merchandise Trade ....................................................................14

3. Selected Countries: Merchandise Trade With the United States as a

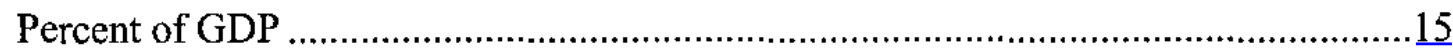

4. Selected Countries: Contribution to Real GDP Growth of Total Net Exports and of Net Exports to the United States, 1971-99...............................................16

5. Industrial and Developing Countries: Fixed Effects Panel Regressions, 1980-98 ........17

6. Developing Countries: Fixed Effects Panel Regressions, 1980-98............................18

7. Industrial Countries: Fixed Effects Panel Regressions, 1980-98_..............................19

8. Industrial and Developing Countries: Fixed Effects Panel Regressions, 1980-98 .........20

9. Industrial and Developing Countries: Fixed Effects Panel Regressions, 1960-98 ..........21

10. Industrial and Developing Countries: Fixed Effects Panel Regressions, 1980-98 ........22

Appendix

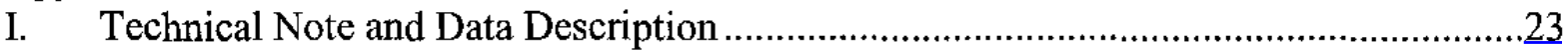

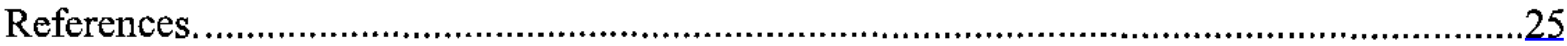




\section{INTRODUCTION}

A common view among economists is that the United States is an engine of the world economy, in the sense that U.S. and world output are closely correlated and movements in U.S. economic growth appear to influence growth in other countries significantly. While this view seems intuitive and plausible, quantitative assessments of just how much U.S. growth has mattered for other countries during recent decades have been relatively neglected in the literature. This paper attempts to fill this gap by providing estimates of the impact of U.S. growth on growth in a large sample of countries during the past two decades in the context of a methodology that is standard in the growth literature.

The significant role of the United States in the world economy would seem to suggest that U.S. growth should have a substantial impact on other countries. A possible channel through which the impact could be transmitted is trade linkages, with a rise in U.S. growth contributing to a rise in import demand, which is reflected directly in an increase in the contribution of net exports to growth in other countries. In addition, trade linkages could result in spillover effects and technology transfers. Another channel is through financial linkages, with U.S. foreign direct and portfolio investment playing a large and growing role in world financial flows.

The paper documents the significance of the United States as a trading partner for other countries, and provides evidence to show that countries' growth rates are significantly influenced by growth in their trading partners. The role of the United States as a global trading partner could, however, encompass several effects on other countries' growth, including both a direct effect through bilateral trade and indirect effects such as a greater impact of U.S. developments on business and consumer confidence in other countries and closer financial linkages that may be associated with closer trade integration. The paper provides estimates of the direct effect of trade with the United States on long-run growth in a number of individual countries. The direct effect is substantial for a number of countries, especially countries in North America and Asia. The direct trade impact, although it is the simplest to quantify, is only one of the possible channels through which the overall impact of U.S. growth is transmitted to the rest of the world.

A quantification of the overall impact of U.S. growth on growth in the rest of the world, implicitly including effects in addition to the direct trade effect, requires a formal econometric analysis. In this paper, the overall impact of U.S. growth on growth in other countries during the past two decades is econometrically estimated in the context of a standard growth model. The impact is initially estimated in a simple growth regression and then in a regression that controls for other generally-accepted determinants of long-run growth. The results suggest that U.S. growth is a significant determinant of growth in a large panel of industrial and developing countries, with an effect as large as one-for-one in some specifications. The impact of U.S. growth turns out to be higher than the impact of growth in the rest of the world. The results are robust to changes in the sample, the period considered, and the inclusion of other growth determinants. 


\section{How Much Does U.S. Economic Growth MatTer FOR GROWTH IN THE REST OF THE WORLD?}

Given its size and close linkages with the world economy, U.S. growth could be expected to have a significant influence on growth in other countries. In 2000, U.S. GDP was equivalent in size to over one-fifth of world GDP on a purchasing power parity basis and nearly a third of world nominal GDP at market exchange rates. The United States accounted for over 20 percent of the expansion in world real GDP during the past two decades, and for nearly a quarter of the expansion during 1992-2000. World and U.S. growth have moved closely together in recent decades, with a correlation coefficient of over 80 percent.

\section{A. The Role of the United States as a Trading Partner}

In general, one would expect a country's economic growth to be positively influenced by growth in its trading partners, reflecting both supply and demand effects. Possible supply effects include the impact of trade on investment, evidence of which includes the fact that openness indicators are generally statistically significant in growth regressions only when the investment share is excluded, ${ }^{2}$ as well as the impact of innovation and technological spillovers from trading partner countries. ${ }^{3}$ In addition to these supply effects, faster growth in partner countries can contribute to a larger market for a country's exports, leading, in the short run, to an increase in the utilization of available resources and, in the longer run, to an increase in investment in the exported goods sectors to satisfy higher future demand. Trade is not the only channel through which the above effects may operate, but it is a potentially important channel.

The impact of U.S. growth on growth in other countries depends in part on the significance of the United States in other countries' external trade. The fact that the United States is a major trading partner for many countries suggests that the trade linkage may be a potentially important channel for transmitting growth effects. Table 1 compares the importance in international trade of the five major trading partners in the world economy: the United States, France, Germany, Japan, and the United Kingdom. The United States has the highest average weight as well as the highest average ranking. On average, it is among the four most important trading partners for other countries, and it is the most trading partner for 49 countries. $^{4}$

${ }^{2}$ See Vamvakidis (2001) for a literature review. Some recent studies, for example Harrison (1996), Rodriguez and Rodrik (1999), are skeptical about the robustness of the relationship between trade and growth.

${ }^{3}$ See, for example, Grossman and Helpman (1989, 1990, 1991), Rivera-Batiz and Romer (1991a, 1991b), and Romer (1990).

${ }^{4}$ The results in the next section do indeed support the argument that the impact of U.S. growth on other countries can be explained by its role as a trading partner. The result is 
During the past few decades, trade with the United States accounted for a substantial share of total trade in a large number of countries (Table 2). ${ }^{5}$ Trade with the United States has been sizeable as a share of GDP in many countries, especially Canada, Mexico, several Asian and Latin American countries, Ireland, Israel, and Saudi Arabia. Growing North American trade integration has been reflected in a strongly rising share of U.S. trade in Canada (Table 3). In the Asia and Pacific region, the United States is a major trading partner for most countries. In Japan, Korea, and the Philippines, greater diversification from an initial trade pattern heavily reliant on the United States was reflected in a declining U.S. trade share through the early 1980s, followed by a stable share of over 20 percent for Korea and around 30 percent for Japan and the Philippines. China's external opening since 1978 is reflected in a doubling of the share of its trade with the United States to nearly 30 percent by 1999 . In Australia and New Zealand, trade diversification contributed to a modest decline in the U.S. trade share, which, however, remained relatively high at around 15 percent.

In Latin America, the share of U.S. trade has been relatively stable for most countries during the past three decades, accounting for over 20 percent of trade in Brazil and Chile in 1999. In the Middle East, U.S. trade has grown in importance, with its share increasing substantially in Egypt, Israel, and Saudi Arabia after the 1970s. Trade with the United States has been less important for European countries, generally accounting for less than 10 percent of their trade (exceptions include Ireland, Switzerland, and the United Kingdom). In South Africa, U.S. trade has accounted for over 10 percent of trade during the past few decades.

The role of the United States as a trading partner suggests that U.S. growth may have a significant impact on other countries, but it does not explicitly indicate the transmission mechanism. The full set of linkages is difficult to examine, but a simple measure that captures the direct effect of trade with the United States on a country's growth is the direct contribution to growth of net exports from the country to the United States. The growth contribution can be calculated by the change in real net exports in the current year as a percent of real GDP in the previous year.

On this basis, net exports to the United States contributed on average $1 / 4$ percentage point annually to real GDP growth in the selected countries during the period 1971-99 (Table 4). The growth contribution was significantly larger in countries with close trading links with the United States (e.g., Canada) as well as in several emerging Asian countries (e.g., China, Malaysia, Thailand). In Latin America, where the United States is traditionally more important as a source of imports than as a destination for exports, net imports from the United States were reflected in a negative net contribution to growth. In Europe, the growth

consistent with the finding that the estimated effect of U.S. growth is larger than that for growth in the rest of the world.

${ }^{5}$ Merchandise trade is examined because data on bilateral trade in nonfactor services are not available for as large a range of countries. 
contribution was small, reflecting the relatively low share of the United States in European countries' trade.

The direct impact on countries' growth of trade with the United States rose during the 1990s compared with previous decades. During the widespread financial crises of 1997-98, trade with the United States was an important factor supporting growth in many countries and preventing the recessions that did occur from being more severe. ${ }^{6}$ In Asia, the crisis led to sharp adjustments in the external sector in many countries, with sharp exchange rate depreciation and significant increases in current account balances, reflecting large increases in net exports, including net exports to the United States.

The direct impact of net exports to the United States on growth, while useful for establishing orders of magnitude, captures only part of the overall impact on growth. ${ }^{7}$ The overall impact is more complex and includes such factors as technology spillovers and effects on sectors not directly involved in bilateral trade. Furthermore, the effects of the United States as a global trading partner may extend beyond just the trade effect, including through such indirect effects as financial linkages as well as domestic consumer and business sentiment being increasingly influenced by developments in the partner economy. In addition, as a country grows in importance as a world trading partner, its foreign direct and portfolio investment flows could become increasingly significant in other countries' capital flows. A fuller analysis of the impact requires formal econometric estimation, which is taken up below.

\section{B. Methodology}

The impact of U.S. growth on growth in the rest of the world can be quantified using fixedeffects panel regression, which allows an analysis of a cross-section of countries over time. The fixed-effects estimator allows the constant term to differ across cross-section units. A simple cross-country estimation would not be valid since the U.S. growth rate enters for all countries in the sample. In contrast, a fixed effects model captures the time series dimension of the U.S. growth effect after controlling for other growth determinants. Also, unlike in the case of a cross-country regression using long period average data, with fixed effects estimation the use of a longer time period provides additional information.

Studies that use alternative methodologies have mainly focused on estimating the impact of foreign output fluctuations on the domestic business cycle. Ahmed and Loungani (1999 and 2001) used a vector error-correction model to estimate the impact of foreign output shocks on domestic output for several groups of emerging market economies in Asia and Latin

\footnotetext{
${ }^{6}$ However, for short-time periods net exports may reflect more of a cyclical element than the true, underlying effect of U.S. growth over longer periods of time.

${ }^{7}$ In addition, the positive effects of strong U.S. growth are not limited to countries that have trade surpluses with the United States.
} 
America, based on annual data for the period $1973-96 .{ }^{8}$ They found the impact of a foreign output shock on domestic output to be roughly one-for-one, after controlling for other external and domestic shocks. Agenor, McDermott, and Prasad (1999) estimated cross correlations using seasonally adjusted and detrended quarterly data to determine the stylized facts of business cycles in developing countries and found that output fluctuations in industrial countries were transmitted at, or near, lag zero to most developing countries.

While such methodologies may be more relevant for analyzing output shocks, a fixed-effects panel approach is more appropriate for analyzing long-run growth, which is the focus of the present paper. In addition, with a fixed-effects panel approach it is possible to control for other explanatory variables in the growth regression and to test the robustness of the estimated U.S. growth impact to changes in model specification.

This paper takes account of recent criticisms of the growth regression framework, mainly that the estimates are very sensitive to the variables included in the regression, and that the results may be driven by outliers (see for example Temple, 2000). The first criticism is addressed by adding the independent variables in stages, starting with a simple regression including only U.S. growth and moving to more general specifications. The second criticism is addressed by testing the robustness of the results by estimating the growth regression for alternative country samples and time periods.

\section{Estimation}

The empirical framework is a growth regression with a specification that is standard in the literature: ${ }^{9}$

(Real GDP per capita growth $)_{i}=\mathbf{c}_{\mathbf{i}}+\boldsymbol{\beta} \mathbf{X}_{\mathbf{i}}+\mathbf{u}, \quad$ for country $\mathrm{i}=1, \ldots, n$

The constant term is different for each country. The dependent variable is the average per capita real GDP growth rate; $\boldsymbol{c}_{\boldsymbol{i}}$ is the matrix of constant terms for each country $i ; \boldsymbol{\beta}$ is the matrix of parameters to be estimated and $\mathbf{u}$ is the error term. $\mathbf{X}_{\mathbf{i}}$ is the matrix of independent variables that includes the standard variables in growth regressions:

- Convergence (the logarithm of per capita real GDP in the initial year of the period under consideration);

- Demographic developments (population growth);

- Investment in physical capital (gross domestic investment as a percent of GDP);

${ }^{8}$ For foreign output, Ahmed and Loungani used an export-weighted aggregate of trading partners' real GDP, a measure that is also used in this paper.

${ }^{9}$ See, for example, Barro and Sala-i-Martin (1995) and Levine and Renelt (1992). 
- Human capital (secondary school enrollment);

- Macroeconomic policies (inflation, government consumption); and

- Trade openness (the share of external trade in GDP). ${ }^{10}$

In addition, $\mathbf{X}_{\mathbf{i}}$ includes:

- U.S. real per capita GDP growth;

- Non-U.S. real per capita GDP growth, to distinguish the impact of U.S. growth from that of growth in the rest of the world; and

- The export-weighted average real per capita GDP growth of trading partners for each country. The coefficient on this variable captures the impact on a country's domestic growth of growth in its export markets, controlling for other growth determinants.

All industrial and developing countries with available data are included in the regressions. ${ }^{11}$ The time period is 1980-98. Each observation is a five-year average, except the initial GDP per capita, which takes the value of the first year of each five-year period, and the last observation, which is a three-year average. ${ }^{12}$ Since the regressions are on growth rates, it is not necessary to test for unit roots and co-integration relationships in the data. The use of a fixed rather than a random-effects model is justified by a Hausman test, which rejects the hypothesis that the individual effects are uncorrelated with the other regressors for most specifications.

The results indicate that U.S. growth has a positive and statistically significant impact on growth in other countries, particularly developing countries. The estimated impact of U.S. growth is distinct from the impact of world growth in general, since it remains statistically significant even when non-U.S. world growth is included in the regressions. Further, the estimated impact of U.S. growth is considerably larger than the estimated impact of growth in the rest of the world, a result that is driven by the impact on developing countries. The results support the argument that the impact of U.S. growth on other countries can be explained by its role as a trading partner.

The regression results reported in Table 5 cover all countries in the sample. The first regression includes only U.S. per capita real GDP growth, while the second includes all other growth determinants and the third includes, in addition, non-U.S. world per capita real GDP

\footnotetext{
${ }^{10}$ In the literature, openness has been measured using a variety of variables, each with its own share of criticism. The trade share is one of the most broadly used and robust measures (see Levine and Renelt, 1992).

${ }^{11}$ All data are from the World Bank's World Development Indicators.

${ }^{12}$ The results are robust to the exclusion of the last observation.
} 
growth. ${ }^{13}$ In the first three regressions, a 1 percent increase in U.S. growth is correlated with an average 0.8 to 1.0 percent increase in growth in other countries. The estimate for non-U.S. world growth in the third regression is also positive ( 0.4 percent), although much smaller than the U.S. coefficient and not statistically significant.

The impact of the other variables on growth is as expected and consistent with the general conclusions in the literature. The coefficient for the trade share is not always statistically significant (see below), but once the investment share is excluded from the regressions it becomes statistically significant for most of the specifications. As discussed above, this result is consistent with the conclusion of previous studies that the impact of openness on growth occurs in part through investment.

The fourth and fifth regressions include the weighted average per capita real GDP growth rate of trading partners. ${ }^{14}$ The estimated coefficient is statistically significant and relatively large, with a 1 percentage point increase in trading partners' growth being correlated with a 0.8 to 0.9 percentage point increase in domestic growth. The coefficient for U.S. growth is positive but no longer statistically significant. ${ }^{15}$ That is, after controlling for growth in countries' trading partners, including the United States, U.S. growth separately does not matter. The significant positive impact of U.S. growth on growth in other countries thus seems to be fully captured by its role as a trading partner.

The regressions in Table 6 include only developing countries. ${ }^{16}$ The results are similar to those for the full sample. The estimates from the first three regressions indicate that a 1 percent increase in U.S. growth is correlated with an average 1 percent increase in developing country growth. The estimates for non-U.S. world growth are again considerably smaller than those for U.S. growth, and are not statistically significant. In the last two regressions, which include trading partners' growth, a 1 percentage point increase in partner country growth is correlated with a 0.6 to 0.7 percentage point increase in domestic growth.

${ }^{13}$ The t-statistics are derived in the conventional way, although adjusted t-statistics based on Moulton's (1990) methodology are discussed in Appendix I.

${ }^{14}$ This is calculated as an average for each five-year period in our sample, using the same weights as in Section II A.

${ }^{15}$ A potential problem with the estimation is that, since trading partners' growth includes the United States, the separate inclusion of U.S. growth raises a possible multicollinearity problem. However, with a serious multicollinearity problem, the estimated coefficient for U.S. growth would change considerably with small changes in the sample and specification, which is not the case here, as discussed below.

${ }^{16}$ As developing countries we define countries with GDP per capita less than $\$ 3,200$ in 1995 prices, in the first half of the 1960s. 
The coefficient for U.S. growth is positive, but no longer statistically significant. As above, the positive impact of U.S. growth thus seems to be driven by the role of the United States as an important trading partner for developing countries.

The regressions in Table 7 include only industrial countries. The impact of U.S. growth is weaker than for developing countries, with smaller estimated coefficients and lower levels of significance. In the first three regressions, a 1 percent increase in U.S. growth is correlated with an average $0.2-0.4$ percent increase in other industrial countries' growth. The coefficient for non-U.S. world growth is now larger and more significant than that for U.S. growth, and close to $1 .{ }^{17}$ U.S. growth is statistically significant only in the second specification (which includes the other growth determinants except for growth in the rest of the world and among trading partners), and even then only at the 10 percent level. ${ }^{18}$ In the last two regressions, a 1 percentage point increase in trading partners' growth is correlated with a 1.1 to 1.2 percentage point increase in domestic growth, a larger impact than in the previous two samples. The coefficient for U.S. growth is not statistically significant in these specifications.

A natural question about the close correlation between U.S. and rest-of-the-world growth is the direction of causality. Results from Granger-causality tests must be interpreted cautiously, however, since the use of five-year averages restricts the sample size, which comprises only eight observations even when the sample period is extended to 1960-98. On this basis, for the full sample of countries, the hypothesis that U.S. growth does not Granger cause growth in the rest of the world was rejected at the 15 percent level, but the reverse could not be rejected.

\section{Extensions}

The results reported in Tables 5-7 are robust to different empirical specifications. The estimates of the impact of U.S. growth on domestic growth remain robust and relatively stable to the inclusion or exclusion of other independent variables, except in the case of the industrial countries. The results are also robust to the inclusion of a time trend in the regression. The $\mathrm{R}^{2}$ is smaller than in cross-country regressions, as the previous literature has found for panel growth regressions (see Barro and Sala-i-Martin (1995)).

The results are robust when alternative samples of countries are considered. Table 8 presents two such sets of results. The first set excludes Latin American countries, to assess the extent

\footnotetext{
${ }^{17}$ Unlike in the case of the developing country regressions, the estimated coefficient for investment is not statistically significant.

${ }^{18}$ However, U.S. growth becomes statistically significant for industrial countries in the first and third specifications after the standard errors are adjusted to take into account any serial correlation in the errors, as recommended by Moulton (1990) and discussed in the Appendix.
} 
to which the earlier results were driven by the large impact of the U.S. economy on these economies given their relatively close integration with the United States. The second set excludes Asian countries, to see how much the earlier results were driven by the large U.S. share in the exports of some of these economies. However, the conclusions are similar to those presented above. U.S. growth has a positive impact on growth in other economies, an impact that is larger than one-for-one in some specifications. The impact seems to operate through the role of the United States as global trading partner, since, as before, when trading partners' growth is included in the regression, U.S. growth is no longer significant.

The results remain robust when a longer period is considered, although some differences stand out. Table 9 reports estimates for the period 1960-98 for the full sample of industrial and developing countries. The impact of U.S. growth was positive and significant, but somewhat smaller than during 1980-98. In the first three regressions, a 1 percentage point increase in U.S. growth is correlated with a $0.4-0.7$ percentage point increase in domestic growth. The coefficient of trading partners' growth is again high and significant, with a 1 percentage point increase being correlated with a $0.9-1.0$ percentage point increase in domestic growth. As before, when trading partners growth is included in the regression, U.S. growth becomes insignificant, suggesting that the trading-partner role was important in explaining the impact of U.S. growth even over the longer period.

Estimating the 1960--98 regression separately for each of the alternative country groups results in similar estimates in terms of significance, but with the estimated coefficient for U.S. growth closer to 0.5, compared with 1 for the period 1980-98. Estimating the same empirical specifications for only the first two decades, 1960-80, results in an estimated coefficient for U.S. growth that is positive but not statistically significant, suggesting that the impact of U.S. growth on other countries has increased in significance during the last two decades. The same conclusion is reached when we test for a structural break during the last two decades in the regression for the period 1960-98, by interacting a dummy variable equal to one in 1980-98 with U.S. growth.

An additional question of interest is how the impact of U.S. growth on other countries compares with the impact of growth in the European Union and Japan. Table 10 reports the results from fixed-effects panel estimations for the period 1980-98. The estimates suggest that EU growth has a significant impact on growth in other countries, albeit a smaller impact than U.S. growth. In the first two regressions, a 1 percent increase in EU growth is correlated with a 0.7 percentage point increase in domestic growth. Like in the case of the United States, the effect may operate through the role of the EU as a major trading partner. When trading partner growth is included, the coefficient for EU growth is no longer statistically significant. Growth in Japan does not seem to have a positive impact on growth of other countries, as its coefficient is not statistically significant, except in the last specification where it is negative. 


\section{Conclusion}

The significant estimated impact of U.S. growth on the rest of the world fills a gap in the literature on the effects of the U.S. economy on other countries, and lends substance to the common view of the United States as an engine of the world economy. For the period 1980-98, the fixed-effects panel regression results for the full sample of industrial and developing countries indicate that the coefficient of U.S. growth is close to one. Once U.S. growth is included in the variable for partner countries' growth it ceases to matter separately, suggesting that the significant impact of U.S. growth on the rest of the world is explained by the role of the United States as a major global trading partner.

In order to better understand how U.S. growth affects the rest of the world, it would be useful to examine the specific channels through which the impact of U.S. growth is transmitted. The trading partner effect of the United States seems to encompass several effects beyond the direct impact of net exports to the United States and, in future research, the framework used in this paper could be extended to analyze the effects of factors such as capital account linkages, co-movements in consumer and business sentiment, and the significant role of U.S. markets in international finance. Such an analysis may also be useful for analyzing the impact of particular economic changes in the United States on growth in other countries. 


\section{$-13-$}

Table 1. Selected Countries: Role as Trading Partners for Other Countries

\begin{tabular}{lccc}
\hline Countries & Average Weight & Average Ranking & Number of First Rankings \\
\hline United States & 14.3 & 3.6 & 49 \\
Germany & 9.4 & 4.1 & 21 \\
Japan & 8.8 & 4.8 & 17 \\
France & 8.5 & 5.5 & 22 \\
United Kingdom & 6.6 & 6.1 & 11 \\
\hline
\end{tabular}

Source: Information Noticc System (INS), IMF. 
Table 2. Selected Countries: Merchandise Trade with the United States as a Percent of Total Merchandise Trade

\begin{tabular}{|c|c|c|c|c|c|}
\hline & 1960 & 1970 & 1980 & 1990 & 1999 \\
\hline World & n.a. & 13.3 & 12.2 & 13.0 & 15.5 \\
\hline Canada & 63 & 69 & 61 & 70 & 78 \\
\hline Japan & 46 & 32 & 21 & 29 & 28 \\
\hline New Zealand & 13 & 16 & 13 & 14 & 15 \\
\hline Australia & 13 & 19 & 16 & 17 & 14 \\
\hline Austria & 5 & 3 & 2 & 2 & 4 \\
\hline Denmark & 8 & 7 & 4 & 5 & 5 \\
\hline Finland & 5 & 5 & 3 & 5 & 6 \\
\hline France & 9 & 7 & 6 & 6 & 8 \\
\hline Germany & n.a. & n.a. & 6 & 6 & 8 \\
\hline Greece & 4 & 3 & 5 & 6 & 5 \\
\hline Ireland & 7 & 10 & 7 & 10 & 16 \\
\hline Italy & 15 & 10 & 6 & 6 & 8 \\
\hline Netherlands & 13 & 9 & 7 & 7 & 9 \\
\hline Portugal & 4 & 4 & 9 & 5 & 4 \\
\hline Spain & 22 & 16 & 9 & 6 & 5 \\
\hline Sweden & 9 & 7 & 5 & 8 & 8 \\
\hline Switzerland & 11 & 10 & 10 & 8 & 11 \\
\hline United Kingdom & 12 & 12 & 11 & 11 & 14 \\
\hline South Africa & 12 & 10 & 13 & 9 & 12 \\
\hline China & n.a. & n.a. & 14 & 22 & 28 \\
\hline Hong Kong SAR & 17 & 27 & 18 & 10 & 7 \\
\hline India & 23 & 20 & 12 & 13 & 15 \\
\hline Indonesia & 20 & 20 & 21 & 11 & 14 \\
\hline Korca & 67 & 38 & 23 & 26 & 21 \\
\hline Malaysia & n.a. & 12 & 17 & 16 & 21 \\
\hline Philippines & 50 & 40 & 29 & 30 & 30 \\
\hline Singapore & 3 & 9 & 12 & 16 & 16 \\
\hline Thailand & 16 & 14 & 14 & 15 & 19 \\
\hline Turkey & 33 & 27 & 7 & 10 & 9 \\
\hline Egypt & 16 & 6 & 22 & 18 & 17 \\
\hline Israel & 23 & 27 & 20 & 24 & 32 \\
\hline Saudi Arabia & 7 & 5 & 15 & 22 & 23 \\
\hline Argentina & 19 & 17 & 18 & 17 & 17 \\
\hline Brazil & n.a. & 30 & 19 & 26 & 26 \\
\hline Chile & 42 & 23 & 19 & 21 & 22 \\
\hline Mexico & 68 & 82 & 80 & 67 & 67 \\
\hline
\end{tabular}

Sources: MMF Direction of Trade Statistics; and WEO. 
Table 3. Selected Countries: Merchandise Trade with the United States as a Percent of GDP

\begin{tabular}{|c|c|c|c|c|}
\hline & 1970 & 1980 & 1990 & 1999 \\
\hline World & 2.5 & 4.0 & 4.0 & 5.7 \\
\hline Canada & 24.1 & 28.7 & 30.4 & 56.1 \\
\hline Japan & 5.4 & 5.0 & 4.6 & 4.3 \\
\hline New Zealand & 5.8 & 6.2 & 5.7 & 7.1 \\
\hline Australia & 4.2 & 4.4 & 4.4 & 4.3 \\
\hline Austria & 5.2 & 3.0 & 3.0 & 3.3 \\
\hline Denmark & 3.3 & 2.4 & 2.3 & 2.7 \\
\hline Finland & 2.0 & 1.9 & 1.8 & 3.6 \\
\hline France & 1.7 & 1.9 & 2.2 & 3.2 \\
\hline Germany & n.a. & 2.9 & 3.2 & 3.9 \\
\hline Greece & 2.2 & 2.6 & 1.6 & 1.3 \\
\hline Ireland & 6.1 & 6.1 & 9.1 & 18.5 \\
\hline Italy & 2.6 & 2.2 & 1.9 & 2.8 \\
\hline Netherlands & 6.6 & 6.0 & 6.2 & 7.1 \\
\hline Portugal & 3.2 & 4.1 & 2.6 & 2.2 \\
\hline Spain & 2.9 & 2.1 & 1.7 & 1.9 \\
\hline Sweden & 2.9 & 2.8 & 3.6 & 5.1 \\
\hline Switzerland & 5.6 & 6.2 & 4.6 & 7.0 \\
\hline United Kingdom & 4.0 & 4.3 & 4.5 & 5.4 \\
\hline South Africa & 4.3 & 7.3 & 3.1 & 4.7 \\
\hline China & n.a. & 1.6 & 5.4 & 10.0 \\
\hline Hong Kong SAR & 36.3 & 27.1 & 22.5 & 14.9 \\
\hline India & 1.4 & 1.7 & 1.9 & 3.0 \\
\hline Indonesia & 4.2 & 8.2 & 4.9 & 8.6 \\
\hline Korea & 11.6 & 14.6 & 13.3 & 13.3 \\
\hline Malaysia & 8.4 & 16.4 & 20.3 & 38.7 \\
\hline Philippines & 13.4 & 12.1 & 13.8 & 25.9 \\
\hline Singapore & 18.1 & 42.8 & 49.4 & 41.7 \\
\hline Thailand & 4.0 & 6.6 & 10.0 & 16.4 \\
\hline Turkey & 2.2 & 1.0 & 2.3 & 3.2 \\
\hline Egypt & 1.4 & 10.9 & 7.6 & 4.2 \\
\hline Israel & 13.1 & 14.6 & 12.6 & 17.4 \\
\hline Saudi Arabia & 2.3 & 12.9 & 14.1 & 12.0 \\
\hline Argentina & 2.0 & 1.6 & 2.0 & 2.8 \\
\hline Brazil & 4.5 & 5.6 & 2.9 & 4.8 \\
\hline Chile & 2.2 & 6.7 & 10.7 & 9.4 \\
\hline Mexico & 7.5 & 13.9 & 22.5 & 40.8 \\
\hline
\end{tabular}

Sources: IMF Direction of Trade Statistics; and WEO. 
Table 4. Selected Countries: Contribution to Real GDP Growth of Total Net Exports and of Net Exports to the United States, 1971-99 1/

\begin{tabular}{|c|c|c|c|c|c|c|}
\hline & \multicolumn{2}{|c|}{$1971-80$} & \multicolumn{2}{|c|}{$1981-90$} & \multicolumn{2}{|c|}{$1991-99$} \\
\hline & Total & U.S. Trade & Total & U.S. Trade & Total & U.S. Trade \\
\hline Canada & -0.2 & -0.1 & 0.0 & 0.1 & 0.2 & 0.4 \\
\hline Japan & 0.2 & 0.2 & 0.0 & 0.1 & 0.2 & 0.1 \\
\hline New Zealand & n.a. & n.a. & 1.2 & 0.2 & 2.3 & 0.4 \\
\hline Australia & 0.2 & 0.0 & -0.1 & -0.1 & 0.0 & -0.1 \\
\hline Austria & -0.3 & 0.0 & 0.2 & 0.0 & 0.0 & 0.0 \\
\hline Denmark & 0.1 & 0.0 & 0.7 & 0.1 & -0.1 & 0.0 \\
\hline Finland & -0.2 & 0.0 & 0.0 & 0.0 & 1.5 & 0.1 \\
\hline France & 0.0 & 0.0 & 0.0 & 0.0 & 0.3 & 0.1 \\
\hline Germany & n.a. & n.a. & 0.4 & 0.1 & -0.1 & 0.1 \\
\hline Greece & n.a. & n.a. & -1.0 & 0.0 & -1.0 & 0.0 \\
\hline Ireland & -0.4 & -0.2 & 1.4 & -0.1 & 3.8 & 0.9 \\
\hline Italy & 0.1 & 0.0 & 0.2 & 0.1 & 0.2 & 0.1 \\
\hline Netherlands & 0.4 & -0.1 & 0.4 & 0.0 & 0.4 & -0.2 \\
\hline Portugal & 0.7 & 0.0 & -1.1 & 0.0 & -1.5 & 0.0 \\
\hline Spain & 0.0 & 0.0 & -0.3 & 0.0 & 0.0 & 0.0 \\
\hline Sweden & 0.2 & 0.0 & 0.2 & 0.1 & 1.0 & 0.2 \\
\hline Switzerland & 0.0 & 0.0 & -0.3 & 0.1 & -0.3 & 0.0 \\
\hline United Kingdom & 0.1 & 0.0 & -0.4 & 0.0 & -0.2 & 0.0 \\
\hline South Africa & 0.3 & 0.1 & -0.1 & -0.1 & -0.2 & 0.0 \\
\hline China & 0.5 & 0.1 & 0.5 & 0.1 & 1.0 & 0.3 \\
\hline Hong Kong SAR & 0.4 & 0.9 & 0.7 & 0.5 & -0.7 & -0.7 \\
\hline India & n.a. & n.a. & 0.1 & 0.1 & -0.2 & 0.2 \\
\hline Indonesia & 2.8 & 1.1 & -1.8 & -0.4 & 0.7 & 0.3 \\
\hline Korea & n.a. & n.a. & 0.2 & 0.3 & 1.7 & 0.3 \\
\hline Malaysia & 0.9 & 0.3 & 0.7 & 0.2 & 1.4 & 1.5 \\
\hline Philippines & -0.2 & 0.1 & -0.7 & 0.3 & -0.2 & 0.1 \\
\hline Singapore & n.a. & n.a. & 0.5 & 1.3 & 1.5 & 0.0 \\
\hline Thailand & n.a. & n.a. & n.a. & n.a. & 1.6 & 0.7 \\
\hline Turkey & n.a. & n.a. & -0.2 & -0.1 & -0.2 & 0.1 \\
\hline Egypt & -1.7 & -0.6 & -0.4 & 0.0 & -1.2 & -0.2 \\
\hline Israel & n.a. & n.a. & -0.4 & 0.2 & -1.2 & 0.0 \\
\hline Saudi Arabia & 2.3 & 0.3 & 0.5 & 0.8 & 1.0 & -0.4 \\
\hline Argentina & -0.2 & -0.1 & 0.7 & 0.2 & -0.6 & -0.2 \\
\hline Brazil & n.a. & n.a. & 0.0 & 0.0 & -0.1 & -0.1 \\
\hline Chile & -1.2 & -0.3 & 1.3 & 0.4 & -0.6 & -0.2 \\
\hline Mexico & -0.6 & 1.2 & 0.5 & 1.0 & 0.0 & 2.5 \\
\hline
\end{tabular}

Source: Calculations based on IMF Direction of Trade Statistics and World Economic Outlook.

1/ Merchandise trade. Data refer to averages during the periods shown. 
Table 5. Industrial and Developing Countries: Fixed Effects Panel Regressions, 1980-98

\begin{tabular}{|c|c|c|c|c|c|}
\hline Independent Variables & (1) & (2) & (3) & (4) & (5) \\
\hline In (initial GDP per capita) & & $\begin{array}{c}-10.08 \\
(-10.47)\end{array}$ & $\begin{array}{c}-10.03 \\
(-10.44)\end{array}$ & $\begin{array}{l}-5.27 \\
(-5.60)\end{array}$ & $\begin{array}{c}-5.47 \\
(-5.51)\end{array}$ \\
\hline Population growth & & $\begin{array}{c}0.18 \\
(0.53)\end{array}$ & $\begin{array}{c}0.16 \\
(0.50)\end{array}$ & $\begin{array}{c}-0.21 \\
(-0.74)\end{array}$ & $\begin{array}{c}-0.18 \\
(-0.63)\end{array}$ \\
\hline Investment/GDP & & $\begin{array}{c}0.14 \\
(4.00)\end{array}$ & $\begin{array}{l}0.015 \\
(4.07)\end{array}$ & $\begin{array}{c}0.11 \\
(3.00)\end{array}$ & $\begin{array}{c}0.11 \\
(3.04)\end{array}$ \\
\hline Inflation rate & & $\begin{array}{l}-0.002 \\
(-4.83)\end{array}$ & $\begin{array}{l}-0.002 \\
(-4.93)\end{array}$ & $\begin{array}{l}-0.001 \\
(-2.23)\end{array}$ & $\begin{array}{l}-0.001 \\
(-2.16)\end{array}$ \\
\hline Secondary school enrollment & & $\begin{array}{c}0.06 \\
(3.48)\end{array}$ & $\begin{array}{c}0.07 \\
(3.59)\end{array}$ & $\begin{array}{c}0.05 \\
(3.31)\end{array}$ & $\begin{array}{c}0.05 \\
(3.16)\end{array}$ \\
\hline Government consumption/GDP & & $\begin{array}{c}-0.05 \\
(-0.94)\end{array}$ & $\begin{array}{c}-0.05 \\
(-0.85)\end{array}$ & $\begin{array}{c}-0.09 \\
(-1.89)\end{array}$ & $\begin{array}{c}-0.09 \\
(-1.86)\end{array}$ \\
\hline Trade/GDP & & $\begin{array}{c}-0.01 \\
(-0.58)\end{array}$ & $\begin{array}{c}-0.00 \\
(-0.35)\end{array}$ & $\begin{array}{c}0.02 \\
(1.50)\end{array}$ & $\begin{array}{c}0.02 \\
(1.36)\end{array}$ \\
\hline Growth of U.S. GDP per capita & $\begin{array}{c}0.83 \\
(5.27)\end{array}$ & $\begin{array}{c}1.03 \\
(6.32)\end{array}$ & $\begin{array}{c}0.97 \\
(5.81)\end{array}$ & & $\begin{array}{c}0.12 \\
(0.64)\end{array}$ \\
\hline Growth of non-U.S. world GDP per capita & & & $\begin{array}{c}0.36 \\
(1.52)\end{array}$ & & \\
\hline Growth of partner countries & & & & $\begin{array}{c}0.88 \\
(3.95)\end{array}$ & $\begin{array}{c}0.78 \\
(2.92)\end{array}$ \\
\hline R-squared & 0.06 & 0.41 & 0.41 & 0.25 & 0.25 \\
\hline Number of countries & 170 & 147 & 147 & 119 & 119 \\
\hline
\end{tabular}

Note: Dependent variable: GDP per capita growth. $t$-statistics in parentheses. 
Table 6. Developing Countries: Fixed Effects Panel Regressions: 1980-98

\begin{tabular}{|c|c|c|c|c|c|}
\hline Independent Variables & (1) & (2) & (3) & (4) & (5) \\
\hline In (initial GDP per capita) & & $\begin{array}{c}-12.61 \\
(-10.51)\end{array}$ & $\begin{array}{c}-12.58 \\
(-10.47)\end{array}$ & $\begin{array}{c}-6.96 \\
(-5.64)\end{array}$ & $\begin{array}{r}-7.26 \\
(-5.60)\end{array}$ \\
\hline Population growth & & $\begin{array}{c}0.33 \\
(0.84)\end{array}$ & $\begin{array}{c}0.32 \\
(0.81)\end{array}$ & $\begin{array}{c}0.11 \\
(0.34)\end{array}$ & $\begin{array}{c}0.15 \\
(0.43)\end{array}$ \\
\hline Investment/GDP & & $\begin{array}{c}0.19 \\
(4.67)\end{array}$ & $\begin{array}{c}0.20 \\
(4.70)\end{array}$ & $\begin{array}{c}0.18 \\
(3.90)\end{array}$ & $\begin{array}{c}0.18 \\
(3.93)\end{array}$ \\
\hline Inflation rate & & $\begin{array}{l}-0.001 \\
(-4.08)\end{array}$ & $\begin{array}{l}-0.001 \\
(-4.10)\end{array}$ & $\begin{array}{l}-0.001 \\
(-1.20)\end{array}$ & $\begin{array}{l}-0.001 \\
(-1.13)\end{array}$ \\
\hline Secondary school enrollment & & $\begin{array}{c}0.08 \\
(2.69)\end{array}$ & $\begin{array}{c}0.08 \\
(2.70)\end{array}$ & $\begin{array}{c}0.07 \\
(2.47)\end{array}$ & $\begin{array}{c}0.06 \\
(2.31)\end{array}$ \\
\hline Government consumption/GDP & & $\begin{array}{c}-0.05 \\
(-0.87)\end{array}$ & $\begin{array}{c}-0.05 \\
(-0.84)\end{array}$ & $\begin{array}{c}-0.11 \\
(-2.00)\end{array}$ & $\begin{array}{c}-0.11 \\
(-1.96)\end{array}$ \\
\hline Trade/GDP & & $\begin{array}{c}0.00 \\
(0.12)\end{array}$ & $\begin{array}{c}0.00 \\
(0.20)\end{array}$ & $\begin{array}{c}0.02 \\
(1.69)\end{array}$ & $\begin{array}{c}0.02 \\
(1.54)\end{array}$ \\
\hline Growth of U.S. GDP per capita & $\begin{array}{c}1.00 \\
(5.16)\end{array}$ & $\begin{array}{c}1.07 \\
(5.39)\end{array}$ & $\begin{array}{c}1.04 \\
(5.09)\end{array}$ & & $\begin{array}{c}0.18 \\
(0.76)\end{array}$ \\
\hline Growth of non-U.S. world GDP per capita & & & $\begin{array}{c}0.18 \\
(0.61)\end{array}$ & & \\
\hline Growth of partner countries & & & & $\begin{array}{c}0.71 \\
(2.54)\end{array}$ & $\begin{array}{c}0.57 \\
(1.71)\end{array}$ \\
\hline R-squared & 0.07 & 0.48 & 0.48 & 0.30 & 0.30 \\
\hline Number of countries & 132 & 113 & 113 & 87 & 87 \\
\hline
\end{tabular}

Note: Dependent variable: GDP per capita growth. t-statistics in parentheses. 
Table 7. Industrial Countries: Fixed Effects Panel Regressions: 1980-98

\begin{tabular}{|c|c|c|c|c|c|}
\hline Independent Variables & (1) & (2) & (3) & (4) & $(5)$ \\
\hline In (initial GDP per capita) & & $\begin{array}{r}-2.87 \\
(-1.97)\end{array}$ & $\begin{array}{r}-2.75 \\
(-2.00)\end{array}$ & $\begin{array}{r}-3.07 \\
(-2.45)\end{array}$ & $\begin{array}{r}-2.79 \\
(-2.09)\end{array}$ \\
\hline Population growth & & $\begin{array}{r}-1.22 \\
(-2.07)\end{array}$ & $\begin{array}{r}-1.14 \\
(-2.06)\end{array}$ & $\begin{array}{r}-1.26 \\
(-2.39)\end{array}$ & $\begin{array}{r}1.33 \\
(-2.46)\end{array}$ \\
\hline Investment/GDP & & $\begin{array}{r}-0.04 \\
(-0.68)\end{array}$ & $\begin{array}{r}-0.05 \\
(-0.84)\end{array}$ & $\begin{array}{r}-0.06 \\
(-1.18)\end{array}$ & $\begin{array}{r}0.07 \\
(-1.26)\end{array}$ \\
\hline Inflation rate & & $\begin{array}{r}-0.007 \\
(-3.56)\end{array}$ & $\begin{array}{l}-0.007 \\
(-4.13)\end{array}$ & $\begin{array}{l}-0.007 \\
(-4.23)\end{array}$ & $\begin{array}{l}-0.007 \\
(-4.26)\end{array}$ \\
\hline Secondary school enrollment & & $\begin{array}{r}0.01 \\
(0.63)\end{array}$ & $\begin{array}{r}0.02 \\
(0.97)\end{array}$ & $\begin{array}{r}0.02 \\
(1.25)\end{array}$ & $\begin{array}{r}0.02 \\
(1.32)\end{array}$ \\
\hline Government consumption/GDP & & $\begin{array}{r}-0.17 \\
(-1.27)\end{array}$ & $\begin{array}{r}-0.16 \\
(-1.27)\end{array}$ & $\begin{array}{r}-0.18 \\
(-1.49)\end{array}$ & $\begin{array}{r}-0.19 \\
(-1.56)\end{array}$ \\
\hline Trade/GDP & & $\begin{array}{r}-0.01 \\
(-0.44)\end{array}$ & $\begin{array}{r}0.00 \\
(0.18)\end{array}$ & $\begin{array}{r}-0.01 \\
(-0.50)\end{array}$ & $\begin{array}{r}-0.01 \\
(-0.36)\end{array}$ \\
\hline Growth of U.S. GDP per capita & $\begin{array}{c}0.21 \\
(1.04)\end{array}$ & $\begin{array}{r}0.41 \\
(1.70)\end{array}$ & $\begin{array}{r}0.26 \\
(1.12)\end{array}$ & & $\begin{array}{r}-0.17 \\
(-0.64)\end{array}$ \\
\hline Growth of non-U.S. world GDP per capita & & & $\begin{array}{r}0.96 \\
(3.16)\end{array}$ & & \\
\hline Growth of partner countries & & & & $\begin{array}{r}1.09 \\
(3.56)\end{array}$ & $\begin{array}{r}1.21 \\
(3.32)\end{array}$ \\
\hline R-squared & 0.01 & 0.32 & 0.41 & 0.46 & 0.46 \\
\hline Number of countries & 38 & 34 & 112 & 32 & 32 \\
\hline
\end{tabular}

Note: Dependent variable: GDP per capita growth t-statistics in parentheses. 
Table 8. Industrial and Developing Countries: Fixed Effects Panel Regressions: 1980-98

\begin{tabular}{|c|c|c|c|c|c|c|c|c|}
\hline \multirow{2}{*}{$\begin{array}{l}\text { Independent Variables } \\
\ln (\text { initial GDP per capita) }\end{array}$} & \multicolumn{5}{|c|}{ Excluding Latin America } & \multicolumn{3}{|c|}{ Excluding Asia } \\
\hline & & $\begin{array}{r}-10.66 \\
(-10.20)\end{array}$ & $\begin{array}{r}-10.71 \\
(-10.26)\end{array}$ & $\begin{array}{r}-5.98 \\
(-5.61)\end{array}$ & & $\begin{array}{r}-9.02 \\
(-7.24)\end{array}$ & $\begin{array}{r}-8.95 \\
(-7.21)\end{array}$ & $\begin{array}{r}-5.00 \\
(-3.67)\end{array}$ \\
\hline Population growth & & $\begin{array}{r}0.33 \\
(0.96)\end{array}$ & $\begin{array}{r}0.33 \\
(0.95)\end{array}$ & $\begin{array}{r}-0.11 \\
(-0.38)\end{array}$ & & $\begin{array}{r}0.30 \\
(0.79)\end{array}$ & $\begin{array}{r}0.28 \\
(0.73)\end{array}$ & $\begin{array}{r}0.00 \\
(0.00)\end{array}$ \\
\hline Investment/GDP & & $\begin{array}{r}0.13 \\
(3.37)\end{array}$ & $\begin{array}{r}0.13 \\
(3.42)\end{array}$ & $\begin{array}{r}0.08 \\
(2.07)\end{array}$ & & $\begin{array}{r}0.15 \\
(3.85)\end{array}$ & $\begin{array}{r}0.15 \\
(3.88)\end{array}$ & $\begin{array}{r}0.11 \\
(2.61)\end{array}$ \\
\hline Inflation rate & & $\begin{array}{l}-0.002 \\
(-5.30)\end{array}$ & $\begin{array}{l}-0.002 \\
(-5.29)\end{array}$ & $\begin{array}{r}-0.01 \\
(-1.79)\end{array}$ & & $\begin{array}{l}-0.001 \\
(-3.91)\end{array}$ & $\begin{array}{l}-0.001 \\
(-4.02)\end{array}$ & $\begin{array}{l}-0.001 \\
(-2.05)\end{array}$ \\
\hline Secondary school enrollment & & $\begin{array}{r}0.06 \\
(3.25)\end{array}$ & $\begin{array}{r}0.07 \\
(3.38)\end{array}$ & $\begin{array}{r}0.04 \\
(2.33)\end{array}$ & & $\begin{array}{r}0.04 \\
(2.36)\end{array}$ & $\begin{array}{r}0.05 \\
(2.53)\end{array}$ & $\begin{array}{r}0.04 \\
(2.14)\end{array}$ \\
\hline Government consumption/GDP & & $\begin{array}{r}-0.06 \\
(-0.94)\end{array}$ & $\begin{array}{r}-0.06 \\
(-0.87)\end{array}$ & $\begin{array}{r}-0.08 \\
(-1.50)\end{array}$ & & $\begin{array}{r}-0.04 \\
(-0.80)\end{array}$ & $\begin{array}{r}-0.04 \\
(-0.69)\end{array}$ & $\begin{array}{r}-0.10 \\
(-1.94)\end{array}$ \\
\hline Trade/GDP & & $\begin{array}{r}0.00 \\
(0.25)\end{array}$ & $\begin{array}{r}0.01 \\
(0.46)\end{array}$ & $\begin{array}{r}0.03 \\
(2.17)\end{array}$ & & $\begin{array}{r}0.01 \\
(0.93)\end{array}$ & $\begin{array}{r}0.02 \\
(1.25)\end{array}$ & $\begin{array}{r}0.03 \\
(1.91)\end{array}$ \\
\hline Growth of U.S. GDP per capita & $\begin{array}{c}0.87 \\
(4.93)\end{array}$ & $\begin{array}{r}1.15 \\
(6.39)\end{array}$ & $\begin{array}{r}1.10 \\
(5.94)\end{array}$ & $\begin{array}{r}0.27 \\
(1.31)\end{array}$ & $\begin{array}{r}0.87 \\
(5.22)\end{array}$ & $\begin{array}{r}1.10 \\
(6.27)\end{array}$ & $\begin{array}{r}1.01 \\
(5.64)\end{array}$ & $\begin{array}{r}0.33 \\
(1.47)\end{array}$ \\
\hline $\begin{array}{l}\text { Growth of non-U.S. } \\
\text { world GDP per capita }\end{array}$ & & & $\begin{array}{r}0.33 \\
(1.26)\end{array}$ & & & & $\begin{array}{r}0.44 \\
(1.78)\end{array}$ & \\
\hline Growth of partner countries & & & & $\begin{array}{r}0.55 \\
(1.93)\end{array}$ & & & & $\begin{array}{r}0.72 \\
(2.29)\end{array}$ \\
\hline R-squared & 0.06 & 0.45 & 0.45 & 0.23 & 0.07 & 0.37 & 0.38 & 0.27 \\
\hline Number of countries & 146 & 124 & 124 & 96 & 130 & 114 & 114 & 94 \\
\hline
\end{tabular}

Note: Dependent variable: GDP per capita growth. $t$-statistics in parentheses. 
Table 9. Industrial and Developing Countries: Fixed Effects Panel Regressions: 1960-98

\begin{tabular}{|c|c|c|c|c|c|}
\hline Independent Variables & (1) & (2) & (3) & (4) & (5) \\
\hline Ln (initial GDP per capita) & & $\begin{array}{r}-5.11 \\
(-10.39)\end{array}$ & $\begin{array}{r}-4.88 \\
(-9.82)\end{array}$ & $\begin{array}{r}-3.66 \\
(-8.01)\end{array}$ & $\begin{array}{r}-3.64 \\
(-7.96)\end{array}$ \\
\hline Population growth & & $\begin{array}{r}-0.07 \\
(-0.34)\end{array}$ & $\begin{array}{r}-0.11 \\
(-0.53)\end{array}$ & $\begin{array}{r}-0.12 \\
(-0.65)\end{array}$ & $\begin{array}{r}-0.14 \\
(-0.70)\end{array}$ \\
\hline Investment/GDP & & $\begin{array}{r}0.12 \\
(5.79)\end{array}$ & $\begin{array}{r}0.13 \\
(5.86)\end{array}$ & $\begin{array}{r}0.15 \\
(6.92)\end{array}$ & $\begin{array}{r}0.15 \\
(6.82)\end{array}$ \\
\hline Inflation rate & & $\begin{array}{l}-0.002 \\
(-6.33)\end{array}$ & $\begin{array}{l}-0.002 \\
(-6.30)\end{array}$ & $\begin{array}{l}-0.001 \\
(-2.26)\end{array}$ & $\begin{array}{l}-0.001 \\
(-2.27)\end{array}$ \\
\hline Secondary school enrollment & & $\begin{array}{r}0.05 \\
(4.31)\end{array}$ & $\begin{array}{r}0.06 \\
(5.04)\end{array}$ & $\begin{array}{r}0.05 \\
(4.95)\end{array}$ & $\begin{array}{r}0.05 \\
(4.99)\end{array}$ \\
\hline Government consumption/GDP & & $\begin{array}{r}-0.11 \\
(-3.07)\end{array}$ & $\begin{array}{r}-0.10 \\
(-2.85)\end{array}$ & $\begin{array}{r}-0.12 \\
(-3.86)\end{array}$ & $\begin{array}{r}-0.13 \\
(-3.93)\end{array}$ \\
\hline Trade/GDP & & $\begin{array}{r}0.02 \\
(1.93)\end{array}$ & $\begin{array}{r}0.02 \\
(2.36)\end{array}$ & $\begin{array}{r}0.02 \\
(2.85)\end{array}$ & $\begin{array}{r}0.02 \\
(2.94)\end{array}$ \\
\hline Growth of U.S. GDP per capita & $\begin{array}{r}0.71 \\
(0.24)\end{array}$ & $\begin{array}{r}0.52 \\
(4.28)\end{array}$ & $\begin{array}{r}0.40 \\
(3.14)\end{array}$ & & $\begin{array}{r}-0.11 \\
(-0.85)\end{array}$ \\
\hline $\begin{array}{l}\text { Growth of non-U.S. world } \\
\text { GDP per capita }\end{array}$ & & & $\begin{array}{r}0.36 \\
(2.68)\end{array}$ & & \\
\hline Growth of partner countrics & & & & $\begin{array}{r}0.89 \\
(6.15)\end{array}$ & $\begin{array}{r}0.96 \\
(5.76)\end{array}$ \\
\hline R-squared & 0.03 & 0.30 & 0.31 & 0.31 & 0.31 \\
\hline Number of countries & 170 & 147 & 147 & 119 & 119 \\
\hline
\end{tabular}

Note: Dependent variable: GDP per capita growth. t-statistics in parentheses. 
Table 10. Industrial and Developing Countries: Fixed Effects

Panel Regressions: $1980-98$

\begin{tabular}{|c|c|c|c|c|c|c|}
\hline \multirow{2}{*}{$\begin{array}{l}\text { Independent Variables } \\
\text { In (initial GDP per capita) }\end{array}$} & \multicolumn{3}{|c|}{ Impact of Growth in EU } & \multicolumn{3}{|c|}{ Impact of Growth in Japan } \\
\hline & & $\begin{array}{r}-10.64 \\
(-10.01)\end{array}$ & $\begin{array}{r}-5.96 \\
(-5.84)\end{array}$ & & $\begin{array}{r}-9.73 \\
(-9.41)\end{array}$ & $\begin{array}{r}-5.83 \\
(-6.25)\end{array}$ \\
\hline Population growth & & $\begin{array}{r}-0.06 \\
(-0.17)\end{array}$ & $\begin{array}{r}-0.16 \\
(-0.51)\end{array}$ & & $\begin{array}{r}-0.08 \\
(-0.23)\end{array}$ & $\begin{array}{r}-0.01 \\
(-0.03)\end{array}$ \\
\hline Investment/GDP & & $\begin{array}{r}0.15 \\
(3.87)\end{array}$ & $\begin{array}{r}0.12 \\
(3.10)\end{array}$ & & $\begin{array}{r}0.12 \\
(3.28)\end{array}$ & $\begin{array}{r}0.12 \\
(3.22)\end{array}$ \\
\hline Inflation rate & & $\begin{array}{l}-0.002 \\
(-5.17)\end{array}$ & $\begin{array}{l}-0.001 \\
(-1.94)\end{array}$ & & $\begin{array}{r}-0.002 \\
(-5.21)\end{array}$ & $\begin{array}{l}-0.001 \\
(-1.89)\end{array}$ \\
\hline Secondary school enrollment & & $\begin{array}{r}0.10 \\
(4.32)\end{array}$ & $\begin{array}{r}0.07 \\
(3.23)\end{array}$ & & $\begin{array}{r}0.09 \\
(4.15)\end{array}$ & $\begin{array}{r}0.02 \\
(1.37)\end{array}$ \\
\hline Government consumption/GDP & & $\begin{array}{r}-0.04 \\
(-0.70)\end{array}$ & $\begin{array}{r}-0.08 \\
(-1.64)\end{array}$ & & $\begin{array}{r}-0.07 \\
(-1.15)\end{array}$ & $\begin{array}{r}-0.06 \\
(-1.31)\end{array}$ \\
\hline Trade/GDP & & $\begin{array}{r}-0.00 \\
(-0.03)\end{array}$ & $\begin{array}{r}0.01 \\
(0.83)\end{array}$ & & $\begin{array}{r}0.00 \\
(0.02)\end{array}$ & $\begin{array}{r}0.01 \\
(0.52)\end{array}$ \\
\hline Growth of EU GDP per capita & $\begin{array}{r}0.71 \\
(2.74)\end{array}$ & $\begin{array}{r}0.65 \\
(3.07)\end{array}$ & $\begin{array}{r}-0.31 \\
(-0.88)\end{array}$ & & & \\
\hline Growth of Japan GDP per capita & & & & $\begin{array}{c}-0.03 \\
(-0.23)\end{array}$ & $\begin{array}{r}-0.10 \\
(-0.79)\end{array}$ & $\begin{array}{r}-0.49 \\
(-3.82)\end{array}$ \\
\hline Growth of partner countries & & & $\begin{array}{r}1.08 \\
(2.18)\end{array}$ & & & $\begin{array}{r}1.55 \\
(5.54)\end{array}$ \\
\hline R-squared & 0.02 & 0.39 & 0.26 & 0.00 & 0.33 & 0.29 \\
\hline Number of countries & 156 & 133 & 106 & 170 & 147 & 119 \\
\hline
\end{tabular}

Note: Dependent variable: GDP per capita growth. t-statistics in parentheses. 


\section{Technical Note and Data Description}

\section{Technical note}

In the paper, the units (countries) in the regression share some common characteristics, namely U.S. growth in each of the sub-periods in the sample, as well as non-U.S. growth. Moulton (1990) pointed out that when units in a regression share a characteristic, they may share other characteristics too. In that case the regression disturbances may be correlated. Even if the correlation is small, so long as it is positive the standard errors could be seriously biased downward, resulting in a spurious statistical significance. Based on Moulton's methodology, the larger the correlation of the disturbances within each group (within each five-year sub-period of the sample) and the larger the group size, the more biased the estimated standard errors will be. The true covariance matrix should be multiplied by the term $[1+(m-1) \rho]$, where $m$ is the number of observations in each group (in our case, the number of countries in each sub-period) and $\rho$ is the correlation of the disturbances within each group.

Adjusting the estimated standard errors for U.S. and non-U.S. world growth according to Moulton's methodology actually improves the results reported above. The reason is that the average correlation of disturbances within each five-year period, although close to zero, is slightly negative, implying that if anything the standard errors are inflated and the t-statistics should be adjusted upward. The average correlation of the disturbances for the sample of all countries ( 140 countries) turns out to be 0.005 . The estimated covariance matrix should be multiplied by 0.3 , and the estimated standard errors by 0.55 . This means that the adjusted t-statistics for U.S. growth and non-U.S. world growth will be higher by a factor of 1.8 on average. This adjustment increases the significance of the U.S. growth estimates in all samples considered. The estimates become statistically significant even for the industrial countries sample.

\section{Data description}

Data used in the regressions were taken from the World Development Indicators (World Bank, 2000). The following variables were used for the construction of the final variables included in the regressions:

GDP at market prices in constant 1995 U.S. dollars;

Total population;

Gross domestic investment as percent of GDP;

Secondary school enrollment ratio (percent of gross);

CPI annual inflation rate; 
General government consumption as a percent of GDP;

Exports plus imports as a percent of GDP.

For the trade calculations in Tables 2-4, data on bilateral trade in goods in current prices were taken from the IMF Direction of Trade Statistics. Data on aggregate exports and imports in current and constant prices, and on GDP in constant prices, were taken from the World Economic Outlook database. Bilateral trade data in constant prices were calculated by assuming that the share of the United States in a country's real exports and imports was equal to the share in nominal exports and imports. For China, aggregate exports and imports in constant prices were not available on a national accounts basis. The growth rates from the balance of payments data were applied to the 1990 current price data (the base year in the national accounts) to construct a series for real exports and imports. The partner-country growth variable in Tables 5-10 was calculated by weighting the per-capita GDP growth of each country's trading partners by the shares in the country's exports. 


\section{References}

Agenor, Pierre-Richard, McDermott, John, and Eswar Prasad, 1999, "Macroeconomic Fluctuations in Developing Countries: Some Stylized Facts," IMF Working Paper, WP/99/35.

Ahmed, Shaghil and Prakash Loungani, 1999, "Business Cycles in Emerging Market Economies," Monetaria, Volume XXII, Number 4, October-December, Centro de Estudios Monetarios Latinoamericanos (CEMLA).

Ahmed, Shaghil and Prakash N. Loungani, 2001, "Business Cycles in Asia," IMF Working Paper, Forthcoming.

Barro, Robert and Xavier Sala-i-Martin, 1995, Economic Growth, New York: McGraw Hill.

Grossman, Gene and Elhanan Helpman, 1989, "Product Development and International Trade," Journal of Political Economy, 97, 1261-83.

Grossman, Gene and Elhanan Helpman, 1990, "Comparative Advantage and Long Run Growth," American Economic Review, 80, 796-815.

Grossman, Gene and Elhanan Helpman, 1991, Innovation and Growth in the Global Economy, MIT Press, Cambridge MA.

Harrison, Ann, 1996, "Openness and Growth: A Time-series, Cross-Country Analysis for Developing Countries," Journal of Development Economics, 48, 419-447.

Levine, Ross and David Renelt, 1992, "A Sensitivity Analysis of Cross-Country Growth Regressions," American Economic Review, September, 82, 942-63.

Moulton, R. Brent, 1990, "An Illustration of a Pitfall in Estimating the Effects of Aggregate Variables on Micro Units," Review of Economics and Statistics, v72, n2 (May): 334-38.

Rivera-Batiz, Luis and Paul Romer, 1991a, "International Trade with Endogenous Technological Change," European Economic Review, 35, 971-1001.

Rivera-Batiz, Luis and Paul Romer, 1991b, "Economic Integration and Endogenous Growth," Quarterly Journal of Economics, 106, 531-55.

Rodriguez, Francisco and Dani Rodrik, 1999, "Trade Policy and Economic Growth: A Skeptic's Guide to the Cross-National Evidence," NBER Working Paper 7081.

Romer, Paul M., 1990, “Endogenous Technological Change," Journal of Political Economy, 98, S71-102. 
Temple, Jonathan, 2000, "Growth Regressions and What the Textbooks Don't Tell You", Bulletin of Economic Research, 52:3, 181-205.

Vamvakidis, Athanasios, 2001, "How Robust is the Growth-Openness Connection? Historical Evidence," manuscript, IMF. 